\title{
Berufsbedingte Lungen- und Pleuraerkrankungen
}

\section{Anmeldung \& Kontakt:}

Deutsche Röntgengesellschaft e. V.

Ernst-Reuter-Platz 10

10587 Berlin

Frau Birgit Engelhardt

Telefon: 030-916 070-16

E-Mail: engelhardt@drg.de

\section{Weitere Informationen:}

www.drgakademie.de >

Veranstaltungskalender

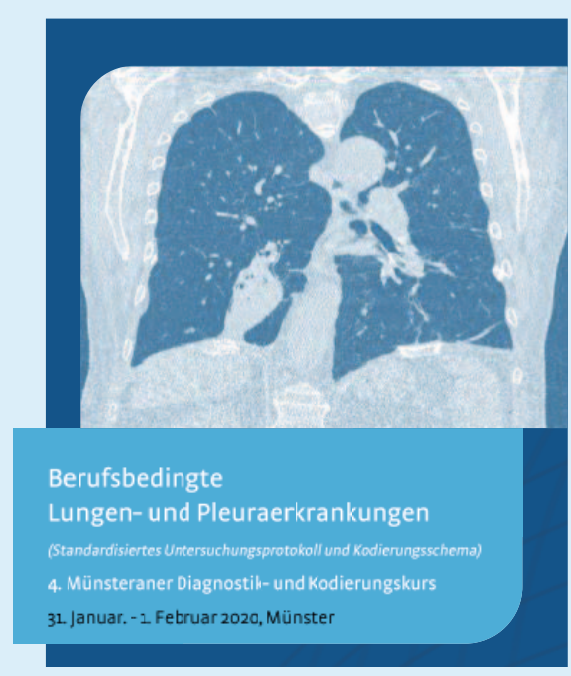

